\title{
Plant growth, nutrients and potentially toxic elements in leaves of yerba mate clones in response to phosphorus in acid soils
}

\author{
JULIERME Z. BARBOSA ${ }^{1}$, ANTONIO C. V. MOTTA ${ }^{1,2}$, RANGEL CONSALTER ${ }^{1}$, \\ GIOVANA C. POGGERE ${ }^{3}$, DELMAR SANTIN ${ }^{4}$ and IVAR WENDLING ${ }^{5}$ \\ 'Programa de Pós-Graduação em Ciência do Solo, Universidade Federal do Paraná/ \\ UFPR, Rua dos Funcionários, 1540, Juvevê, 80035-050 Curitiba, PR, Brazil \\ ${ }^{2}$ Departamento de Ciência do Solo, Universidade Federal do Paraná/UFPR, Rua \\ dos Funcionários, 1540, Juvevê, 80035-050 Curitiba, PR, Brazil \\ ${ }^{3}$ Programa de Pós-Graduação em Ciência do Solo, Universidade Federal de Lavras/UFLA, \\ Campus Universitário, Caixa Postal 3037, 37200-000 Lavras, MG, Brazil \\ ${ }^{4}$ Engenheiro Florestal, PhD., Autônomo, Rua Saulo de Carvalho, 1006, Jardim Esperança, 89460-000 Canoinhas, SC, Brazil \\ ${ }^{5}$ Empresa Brasileira de Pesquisa Agropecuária/EMBRAPA, Centro Nacional de Pesquisas de \\ Florestas, Estrada da Ribeira, Km 111, Guairatuba, 83411-000 Colombo, PR, Brazil
}

Manuscript received on October 11, 2016; accepted for publication on September 6, 2017

\begin{abstract}
Native to subtropical region of South America, yerba mate is responsive to P under some conditions, but the degree of influence of genetic and soil on the growth and composition of the leaf is unknown. The aim of study was to evaluate plant growth, nutrients and potentially toxic elements in leaves of yerba mate clones in response to $\mathrm{P}$ application in acid soils. In greenhouse condition, two yerba mate clone seedlings were grown (210 days) in pots, each clone in a completely randomized design in factorial scheme (with and without $\mathrm{P}$; four acid soils). The elemental composition of leaves and the growth of plants were determined. Phosphorus promoted plant growth, but this was not accompanied by increased $\mathrm{P}$ in leaf tissue in all conditions tested. The P effect on the elemental composition varied: decrease/null ( $\mathrm{N}, \mathrm{K}, \mathrm{Mg}, \mathrm{Mn}$, $\mathrm{Cu}, \mathrm{Ni}, \mathrm{B}, \mathrm{Mo}, \mathrm{Al}, \mathrm{Cd})$; increase/null (C/N, C, Ca, Fe, V); increase/decrease/null (Zn, Ba, Pb) and; null (Cr). The soils affect the elemental composition of the leaves, especially Mn, with accumulation greater than $1000 \mathrm{mg} \mathrm{kg}^{-1}$. The $\mathrm{Ba}, \mathrm{Pb}, \mathrm{Al}$ and $\mathrm{Zn}$ in the leaves varied among clones. Yerba mate response to $\mathrm{P}$ was affected by edaphic and plant factors.
\end{abstract}

Key words: Ilex paraguariensis St.Hil, medicinal plant, metal accumulation, soil fertility, trace elements.

\section{INTRODUCTION}

Yerba mate is a native tree from the subtropical region of South America. Traditionally, the yerba mate consumption in Brazil, Argentina, Paraguay

Correspondence to: Julierme Zimmer Barbosa

E-mail: barbosajz@yahoo.com.br and Uruguay is as mate or chimarrão (infusion with hot water) and tererê (infusion with cold water). Moreover, industrialized beverages, nutraceuticals and cosmetics have also been developed from the plant leaves. But, recently, the consumption of yerba mate products has expanded to different countries, like: Australia, France, Germany, Italy, 
Japan, Korea, Russia, Spain, Syria and United States (Cardozo Junior and Morand 2016).

The soils where yerba mate is found are notable due to their high acidity $\left(\mathrm{pH}-\mathrm{CaCl}_{2} 3.7\right.$ to 4.9 ), indicating that the species is tolerant to this extreme condition, especially in relation to Al toxicity (Reissmann et al. 1999). However, according to the authors, the relationship between exchangeable $\mathrm{Al}$ in the soil and the $\mathrm{Al}$ in plant is not always clear. The low pH of very acid soils can affect the soil element dynamics, especially the increase of $\mathrm{Cu}, \mathrm{Fe}, \mathrm{Mn}, \mathrm{Ni}, \mathrm{Zn}, \mathrm{Al}, \mathrm{Pb}$ and $\mathrm{Cd}$ availability, and the decreased $\mathrm{Mo}$ and $\mathrm{P}$ availability (Kabata- Pendias 2011). The soil P availability undergoes interference of clay mineral specific adsorption (Gérard 2016). In the case of low soil P availability, plants increase the root exudate molecules that solubilize non-available forms of $\mathrm{P}$, which can solubilize other nutrients or toxic elements. Moreover, the $\mathrm{P}$ promotes the plant metabolism, therefore: total root exudation of molecules (with genotypic variation within the same plant species) may increase and affect the solubilization of soil constituents (Elanchezhian et al. 2015).

By presenting low leaf $\mathrm{P}$ content and being found in low fertility acid soils (Reissmann et al. 1999, Barbosa et al. 2015), yerba mate could be considered a species undemanding in P. In contrast, there have been reported increases in species growth in response to $\mathrm{P}$ application, even at high rates, indicating that yerba mate is $\mathrm{P}$ responsive (Ceconi et al. 2007, Santin et al. 2008). Assessing the influence of $\mathrm{P}$ on the elemental composition of yerba mate seedling leaves, Santin et al. (2013) observed alterations in $\mathrm{N}, \mathrm{P}, \mathrm{K}, \mathrm{Ca}, \mathrm{Mg}, \mathrm{Fe}, \mathrm{Mn}$, $\mathrm{Cu}$ and $\mathrm{Zn}$. However, the effects of $\mathrm{P}$, genotype and soil factors on a wide range of elements in the yerba mate leaves and plant growth is unknown. Thus, the aim of this study was to evaluate plant growth, nutrients and potentially toxic elements in leaves of yerba mate clones in response to $\mathrm{P}$ application in acid soils.

\section{MATERIALS AND METHODS}

Samples were collected from the surface layer (020) of four acid soils [a Ferralsol (FER) and three Cambisol (CAM), IUSS Working Group (2015); Latossolo and Cambissolo, Brazilian classification], in Jaguariaíva-PR, Pinhais-PR, São Mateus do SulPR and Rio dos Cedros-SC. The parent material of soils was sandstone, argillite, shale and argillite/ siltite, respectively, for FER, CAM1, CAM2 and CAM3. After, soil samples were air dried and passed through a $4 \mathrm{~mm}$ sieve. For characterization of the soil samples, physical and chemical analyses were conducted. Results are shown in Table I.

In December 2013 two experiments were installed under greenhouse conditions (in CuritibaPR, Brazil). The first with yerba mate seedlings of Clone 1 (BRS 408) and the second with seedlings of Clone 2 (BRS BLD Aupaba). The clones were selected from a provenance/progenies test deployed in 1997, in Ponta Grossa-PR, propagated by minicutting, according to the methodology described in Wendling and Brondani (2015). In both experiments a completely randomized design was used with treatments in a factorial arrangement $2 \times 4$ (with or without P; four soils), with six replications. Each experimental unit consisted of a plastic pot $\left(8 \mathrm{dm}^{-3}\right)$ containing $6.5 \mathrm{~kg}$ of soil and one yerba mate seedling.

The $\mathrm{P}$ treatments were: absence of $\mathrm{P}$ (control); $250 \mathrm{mg} \mathrm{P} \mathrm{kg}^{-1}$ soil, half applied as $\mathrm{NH}_{4} \mathrm{H}_{2} \mathrm{PO}_{4}(\mathrm{PA})$ and half applied as $\mathrm{KH}_{2} \mathrm{PO}_{4}(\mathrm{PA})$. Additionally, $\mathrm{K}(\mathrm{KCl})$ and $\mathrm{N}\left[\left(\mathrm{NH}_{2}\right)_{2} \mathrm{CO}\right]$ were applied totaling (considering the application of those nutrients in the P treatment) $200 \mathrm{mg} \mathrm{K} \mathrm{kg}^{-1}$ and $100 \mathrm{mg} \mathrm{N}$ $\mathrm{kg}^{-1}$, respectively. Two and four months after the installation of the experiments out the application of $50 \mathrm{mg} \mathrm{N} \mathrm{kg}^{-1}$ was carried, using $\left(\mathrm{NH}_{4}\right)_{2} \mathrm{SO}_{4}$ and $\left(\mathrm{NH}_{2}\right)_{2} \mathrm{CO}$ as source, respectively. 
TABLE I

Pre-planting granulometric and chemical analyses of four soils used in the experiments.

\begin{tabular}{|c|c|c|c|c|c|c|c|c|c|c|c|}
\hline Soil $^{1}$ & Sand $^{2}$ & Silt & Clay & $\begin{array}{c}\mathrm{pH} \\
\mathrm{CaCl}_{2}\end{array}$ & $\mathrm{H}+\mathrm{Al}^{3+}$ & $\mathrm{Al}^{3+}$ & $\mathrm{Ca}^{2+}$ & $\mathrm{Mg}^{2+}$ & $\mathrm{K}^{+}$ & CEC & $\mathrm{m}$ \\
\hline & \multicolumn{4}{|c|}{---------- $\mathrm{g} \mathrm{kg}^{-1}$---------- } & \multicolumn{6}{|c|}{ - } & $\%$ \\
\hline FER & 850 & 25 & 125 & 3.80 & 5.00 & 1.60 & 0.20 & 0.10 & 0.02 & 5.32 & 83 \\
\hline CAM1 & 475 & 212 & 313 & 3.90 & 15.20 & 4.70 & 1.10 & 0.35 & 0.09 & 16.74 & 75 \\
\hline CAM2 & 337 & 238 & 425 & 3.70 & 16.30 & 8.00 & 1.80 & 1.00 & 0.26 & 19.36 & 72 \\
\hline \multirow[t]{3}{*}{ CAM3 } & 275 & 225 & 500 & 3.50 & 15.20 & 14.00 & 0.50 & 0.70 & 0.14 & 16.54 & 91 \\
\hline & $\mathrm{P}$ & $\mathrm{Fe}$ & $\mathrm{Mn}$ & $\mathrm{Cu}$ & $\mathrm{Zn}$ & $\mathrm{Ni}$ & B & $\mathrm{Ba}$ & Co & $\mathrm{Cr}$ & $\mathrm{Pb}$ \\
\hline & \multicolumn{11}{|c|}{ 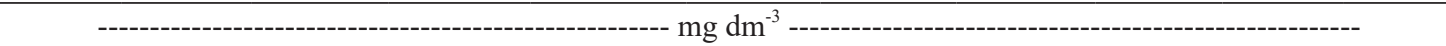 } \\
\hline FER & 3.00 & 170 & 2.00 & 1.00 & 0.30 & 0.04 & 0.68 & 1.00 & 0.070 & 0.27 & 1.50 \\
\hline CAM1 & 2.20 & 38 & 3.00 & 0.25 & 4.40 & 0.08 & 0.43 & 2.00 & 0.004 & 0.16 & 0.72 \\
\hline CAM2 & 6.20 & 120 & 48.70 & 1.70 & 1.80 & 0.18 & 0.57 & 3.34 & 0.050 & 0.09 & 0.39 \\
\hline \multirow[t]{3}{*}{ CAM3 } & 2.50 & 267 & 2.10 & 1.00 & 1.70 & 0.16 & 0.59 & 3.41 & 0.170 & 0.37 & 0.46 \\
\hline & As & $\mathrm{V}$ & Mo & $\mathrm{Cd}$ & $\mathrm{Pc}-\mathrm{Al}_{2} \mathrm{O}_{3}$ & $\begin{array}{c}\mathrm{Pc}- \\
\mathrm{Fe}_{2} \mathrm{O}_{3}\end{array}$ & $\begin{array}{c}\mathrm{Pc}- \\
\mathrm{MnO}_{2}\end{array}$ & $\begin{array}{c}\mathrm{Cr}- \\
\mathrm{Al}_{2} \mathrm{O}_{3}\end{array}$ & $\begin{array}{c}\mathrm{Cr}- \\
\mathrm{Fe}_{2} \mathrm{O}_{3}\end{array}$ & $\begin{array}{c}\mathrm{Cr}- \\
\mathrm{MnO}_{2}\end{array}$ & $\mathrm{OC}$ \\
\hline & \multicolumn{2}{|c|}{$\mathrm{mg} \mathrm{dm}-3$} & \multicolumn{2}{|c|}{$\mu \mathrm{g} \mathrm{dm}{ }^{-3}$} & \multicolumn{6}{|c|}{--------------------------- $\mathrm{g} \mathrm{kg}^{-1}$--------------------------- } & $\mathrm{g} \mathrm{dm}^{-3}$ \\
\hline FER & 0.15 & 0.99 & 2.19 & 4.15 & 1.52 & 1.54 & 0.001 & 7.07 & 3.53 & nd & 15.0 \\
\hline CAM1 & 0.09 & 0.10 & 17.00 & 8.90 & 4.27 & 7.14 & 0.015 & 9.56 & 23.77 & nd & 30.0 \\
\hline CAM2 & 0.16 & 0.06 & 5.00 & 10.00 & 2.35 & 2.96 & 0.175 & 7.66 & 21.23 & 0.10 & 32.0 \\
\hline CAM3 & 0.06 & 0.20 & 2.80 & 11.00 & 2.73 & 4.75 & 0.005 & 6.92 & 22.66 & nd & 20.0 \\
\hline
\end{tabular}

${ }^{1}$ FER - Ferralsol; CAM - Cambisol. ${ }^{2}$ Soil analyses were conducted on thin $(2 \mathrm{~mm})$ air dry soil; Sand, silt and clay (method hydrometer); $\mathrm{pH}\left(\mathrm{CaCl}_{2} 0.01 \mathrm{~mol} \mathrm{~L}{ }^{-1}\right) ; \mathrm{Ca}^{2+}, \mathrm{Mg}^{2+}, \mathrm{Al}^{3+}$ (extracted with $\left.\mathrm{KCl} 1 \mathrm{~mol} \mathrm{~L}^{-1}\right) ; \mathrm{H}+\mathrm{Al}^{3+}$ (calcium acetate 0.5 mol L extraction); organic carbon (OC) (volumetric method by potassium dichromate); $\mathrm{K}^{+}, \mathrm{P}, \mathrm{Mn}, \mathrm{Fe}, \mathrm{Cu}$ and $\mathrm{Zn}$ (Mehlich-1 extraction; soil:solution ratio 1:10); $\mathrm{As}, \mathrm{Ba}, \mathrm{Co}, \mathrm{Co}, \mathrm{Cr}, \mathrm{Ni}, \mathrm{B}, \mathrm{Pb}, \mathrm{V}, \mathrm{Cd}$ and $\mathrm{Mo}$ (Mehlich-1 extraction; soil:solution ratio 1:5); $\mathrm{Pc}$ and $\mathrm{Cr}$, respectively, indicate poor crystalline (extracted with ammonium oxalate) and crystalline forms (extracted with sodium dithionitecitrate-bicarbonate) $\mathrm{CEC}=$ cation exchange capacity; $\mathrm{m}=\mathrm{Al}^{3+}$ saturation. $\mathrm{nd}=$ no detected.

The temperature control of the greenhouse had air extractors and an air humidifying system and automatically activates when the temperature reached $28{ }^{\circ} \mathrm{C}$, remaining in operation until the temperature drops below $28{ }^{\circ} \mathrm{C}$. The plants were grown in partially shaded condition (50\% aluminet), which is the native condition of the yerba mate (Reissmann et al. 1999). Irrigation was conducted with deionized water according to plant needs.

After 210 days we determined plant height (neck to the main meristem) and expanded leaves were collected in the second quartile region (base to apex) of the plants. The leaves were washed with deionized water, dried $\left(48 \mathrm{~h}\right.$ at $\left.65^{\circ} \mathrm{C}\right)$, weighed on a digital scale $(0.001 \mathrm{~g})$, ground in a Wiley knifetype mill and passed through a $1 \mathrm{~mm}$ sieve. The plants were then cut at $5 \mathrm{~cm}$ above the soil surface, and the aerial part dried $\left(48 \mathrm{~h}\right.$ at $\left.65^{\circ} \mathrm{C}\right)$ and weighed on a digital scale $(0.001 \mathrm{~g})$.

The leaf $\mathrm{C}$ and $\mathrm{N}$ contents were determined by dry combustion with a nonmetal element analyzer (Elementar, Vario EL III), using about 20 $\mathrm{mg}$ of leaves. For analysis of the other elements the Martins and Reissmann (2007) adapted methodology was used. About $2 \mathrm{~g}$ of leaves were ashed in porcelain crucibles in a muffle furnace at $500^{\circ} \mathrm{C}$ for 4 hours. Afterwards, the ash was digested with $\mathrm{HCl}\left(3 \mathrm{~mol} \mathrm{~L}^{-1}\right)$ and the crucibles remained in the muffle at $500^{\circ} \mathrm{C}$ for 4 more hours. Next, $10-\mathrm{ml}$ of $\mathrm{HCl}\left(3 \mathrm{~mol} \mathrm{~L}^{-1}\right)$ was then added and the crucibles remained on a hot plate at $70{ }^{\circ} \mathrm{C}$ for 10 minutes. After this period, the digestion solutions were filtered ( $8 \mu \mathrm{m}$ pore diameter filter paper) and the extracts collected in 50-ml volumetric flasks. To 
gauge the volumetric flasks, deionized water was used. The following elements were determined in the obtained extracts: $\mathrm{P}, \mathrm{K}, \mathrm{Ca}, \mathrm{Mg}, \mathrm{Fe}, \mathrm{Mn}, \mathrm{Zn}$, $\mathrm{Cu}, \mathrm{Ni}, \mathrm{B}, \mathrm{Mo}, \mathrm{Co}, \mathrm{As}, \mathrm{Cd}, \mathrm{Pb}, \mathrm{Ba}, \mathrm{Cr}$ and $\mathrm{V}$; using optical emission spectrometer with inductively coupled plasma (ICP-OES) (Varian, 720-ES).

For each clone a completely randomized design was used with treatments in a 2 x 4 factorial arrangement (two levels of $\mathrm{P} x$ four soils) with six replications. The data were subjected to analysis of variance $(p<0.05)$ and the Tukey test $(p<0.05)$. To explore more generally the elementary profile of yerba mate clones, the data from the two experiments were subjected to analysis of variance $(\mathrm{p}<0.05)$ following a completely randomized design with two treatments (Clone 1 x Clone 2) with 48 replications. In addition, the interactions between the elements were analyzed by Pearson correlations and principal component analysis (PCA).

\section{RESULTS AND DISCUSSION}

\section{PLANT GROWTH}

The results presented in Figure 1 indicate variation in degree of P response between clones and soils. In general, CAM2 soil showed higher growth for both clones in the absence of $\mathrm{P}$ and lower response to $\mathrm{P}$ application, which was expected, as was the soil with higher available P content. Clone 2 was shown to be less productive in the absence of $\mathrm{P}$ and more responsive to $\mathrm{P}$ application: increase of $57 \%$ to $500 \%$ and $34 \%$ to $1000 \%$ in aerial part dry matter for Clone 1 and Clone 2, respectively. The low explanatory power of the $\mathrm{P}$ effect on height values is due to the intense lateral branching that occurred in the plants, affecting the main stem growth. In other studies with yerba mate in pots, positive effect of $\mathrm{P}$ in height and dry matter production of plants have been found, with a maximum $P$ rate increases until $450 \mathrm{mg} \mathrm{kg}^{-1}$ (Ceconi et al. 2007, Santin et al. 2008, 2013).

\section{MACRONUTRIENTS}

In the absence of fertilization, the leaves presented low $\mathrm{P}$ content values, less than $1 \mathrm{~g} \mathrm{~kg}^{-1}$ (Table II). The phosphate fertilizer provided a higher increase ( 2 times) in the $P$ content in leaves of two yerba mate clones in FER, CAM1 and CAM3 soils (Table II), the quite significant increase normally is observed only in condition of P deficiency. For CAM2 soil, lower increases in $\mathrm{P}$ content in the leaves are compatible with the higher available $\mathrm{P}$ content in that soil (Table I) and lower increases in dry matter production in response to fertilization (Table II). Although they obtained higher production, the plants that grew in CAM1 and CAM2 soils, obtained values below $1 \mathrm{~g} \mathrm{P} \mathrm{kg}^{-1}$, indicating that the leaf content should be used with caution and possibly associated with other indicators for nutritional diagnosis of $\mathrm{P}$.

In a study in pots, Santin et al. (2013) reported increased $\mathrm{P}$ content in leaves and roots of yerba mate adjusted in a quadratic model. A similar effect was observed by Lin et al. (2009) in tea leaves (Camellia sinensis) grown in nutrient solution with different $\mathrm{P}$ levels. That is, as soil $\mathrm{P}$ availability increases, the changes in leaf $\mathrm{P}$ content are less. Thus, this may explain why there was no significant effect of $\mathrm{P}$ fertilization on $\mathrm{P}$ content of yerba mate leaves grown in soil with higher initial P availability (CAM2) (Table II). Regarding the variations provided by soils, we found that, except for Clone 2 in the absence of $\mathrm{P}$ application, the highest $\mathrm{P}$ content in the leaves did not occur in soil with the highest initial P availability (CAM2). But, the increases in growth confirms the importance of $\mathrm{P}$ fertilization in the initial growth phase, which suggests the possibility of being one of the reasons for low crop productivity rates in unfertilized systems.

The $\mathrm{C} / \mathrm{N}$ ratio and $\mathrm{C}, \mathrm{N}$ and $\mathrm{Mg}$ contents in Clone 1 leaves varied with the phosphate fertilizer and soil, whereas the $\mathrm{K}$ content varied with 


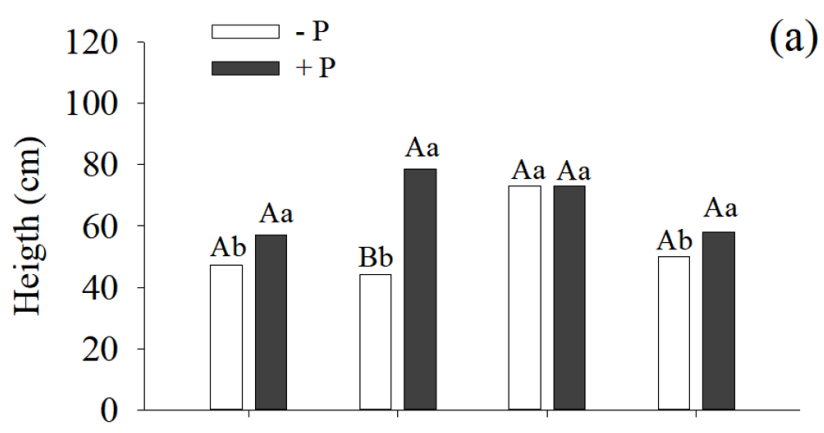

(a) 120

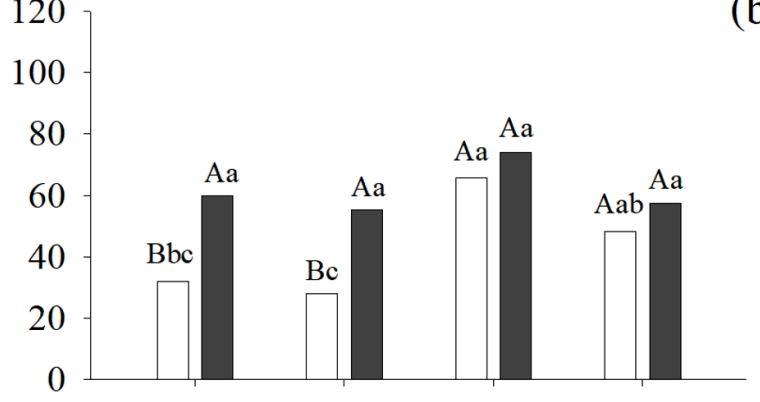

(c)

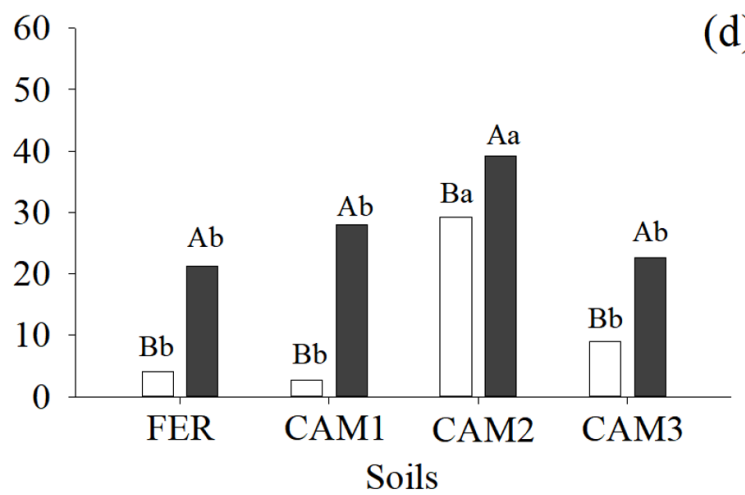

Figure 1 - Height $(\mathbf{a}, \mathbf{b})$ and aerial part dry matter $(\mathbf{c}, \mathbf{d})$ of yerba mate clones in response to P fertilization. at 210 days after experiment installation. Clone 1 ( $a$ and c). Clone 2 ( $b$ and d). Soils: FER - Ferralsol; CAM - Cambisol. Different values for lowercase (soils effect) and uppercase letters (P effect) indicate significant difference by the test Tukey $(\mathrm{p}<0.05)$.

phosphate, and $\mathrm{Ca}$ content varied between soils. On the other hand, in Clone 2 leaves the $\mathrm{C} / \mathrm{N}$ ratio and $\mathrm{N}, \mathrm{K}$ and $\mathrm{Ca}$ contents varied with the phosphate fertilizer and soil, while $\mathrm{C}$ and $\mathrm{Mg}$ varied with phosphate (Table II).

There was a positive effect of phosphate fertilization in $\mathrm{C}$ content in leaves for most conditions (Table II). Accordingly, evaluating tea, Lin et al. (2009) found that plants with $\mathrm{P}$ deficiency had lower electron transport capacity, which reduced ATP levels and impaired the rubisco enzyme (ribulose-1,5-bisphosphate carboxylase/ oxygenase) and, consequently, there was limitation in $\mathrm{CO}_{2}$ assimilation. In addition to these physiological factors, changes in the leaf anatomy (leaf blade/ribs ratio, leaf thickness) may have contributed to the findings, which deserves attention in future studies. The variation in $\mathrm{C}$ content in the leaves of yerba mate clones was low, corroborating
Barbosa et al. (2015), evaluating leaves and fruits of plants from four yerba mate origins.

The $\mathrm{P}$ fertilization decreased $\mathrm{N}$ content in leaves for three conditions in Clone 1 (FER, CAM1 and CAM3) and one for Clone 2 (soil CAM1) (Table II). In contrast, Santin et al. (2013) found small increase of $\mathrm{N}$ contents (Zero $\mathrm{P}=25 \mathrm{~g} \mathrm{~N} \mathrm{~kg}^{-1}$; $200 \mathrm{mg} \mathrm{P}=27 \mathrm{~g} \mathrm{~N} \mathrm{~kg}^{-1}$ ) in the yerba mate leaves in response to $\mathrm{P}$ fertilization. This variation between the studies can be related to the age of the plants (present study, plants with 210 days of growth; Santin and collaborators, plants with 120 days). As a consequence of the $\mathrm{N}$ decrease, combined or not with a $\mathrm{C}$ increase, there was found an increase in the $\mathrm{C} / \mathrm{N}$ ratio (Table II). Still, an inverse relationship between growth and the $\mathrm{C} / \mathrm{N}$ ratio was found, and in plants that had higher (with $\mathrm{P}$ fertilization in CAM1 and CAM2 soils) and lower growth (without $\mathrm{P}$ fertilization in FER and CAM1 
TABLE II

Carbon/nitrogen ratio $(\mathrm{C} / \mathrm{N})$ and $\mathrm{C}, \mathrm{N}, \mathrm{K}, \mathrm{Ca}, \mathrm{Mg}$ and $\mathrm{P}$ contents $\left(\mathrm{g} \mathrm{kg}^{-1}\right)$ in leaves of yerba mate clones in response to $\mathrm{P}$ fertilization, at 210 days after installation of the experiments ${ }^{1}$.

\begin{tabular}{|c|c|c|c|c|c|c|c|c|c|c|c|}
\hline & & \multicolumn{4}{|c|}{ Clone 1} & \multirow[b]{2}{*}{ Mean } & \multicolumn{5}{|c|}{ Clone 2} \\
\hline & & FER & CAM1 & CAM2 & CAM3 & & FER & CAM1 & CAM2 & CAM3 & Mean \\
\hline \multirow{3}{*}{$\mathrm{C} / \mathrm{N}$} & $-P$ & $14.3 \mathrm{Bb}$ & $12.9 \mathrm{Bb}$ & 18.6Aa & $13.9 \mathrm{Bb}$ & 14.9 & 17.1Aab & $11.0 \mathrm{Bc}$ & 19.6Aa & $16.5 \mathrm{Ab}$ & 16.0 \\
\hline & $+\mathrm{P}$ & $18.8 \mathrm{Ab}$ & $21.8 \mathrm{Aa}$ & 20.7Aab & $18.6 \mathrm{Ab}$ & 19.7 & $18.0 \mathrm{Ab}$ & 19.0Aab & $21.2 \mathrm{Aa}$ & 18.6Aab & 19.1 \\
\hline & Mean & 16.3 & 17.3 & 19.6 & 16.0 & & 17.4 & 15.0 & 20.4 & 17.5 & \\
\hline \multirow{3}{*}{$\mathrm{C}$} & $-\mathrm{P}$ & 424Bab & $416 \mathrm{Bb}$ & $435 \mathrm{Aa}$ & $423 \mathrm{Bab}$ & 425 & 434 & 417 & 435 & 427 & $428 \mathrm{~B}$ \\
\hline & $+\mathrm{P}$ & $441 \mathrm{Aa}$ & 448Aa & $435 \mathrm{Aa}$ & $442 \mathrm{Aa}$ & 441 & 436 & 433 & 435 & 432 & $434 \mathrm{~A}$ \\
\hline & Mean & 432 & 432 & 435 & 433 & & 435 & 425 & 435 & 430 & \\
\hline \multirow{3}{*}{$\mathrm{N}$} & $-\mathrm{P}$ & 29.9Aa & 33.0Aa & $23.5 \mathrm{Ab}$ & $30.6 \mathrm{Aa}$ & 29.2 & $25.4 \mathrm{Ab}$ & 38.1Aa & $22.2 \mathrm{Ab}$ & $26.3 \mathrm{Ab}$ & 28.0 \\
\hline & $+\mathrm{P}$ & $23.8 \mathrm{Ba}$ & $20.7 \mathrm{Ba}$ & $21.3 \mathrm{Aa}$ & $22.4 \mathrm{Ba}$ & 22.1 & $24.5 \mathrm{Aa}$ & $23.9 \mathrm{Ba}$ & $21.8 \mathrm{Aa}$ & $23.5 \mathrm{Aa}$ & 23.4 \\
\hline & Mean & 26.9 & 26.8 & 22.4 & 26.5 & & 24.9 & 31.0 & 22.0 & 24.9 & \\
\hline \multirow{3}{*}{$\mathrm{K}$} & $-P$ & 12.5 & 11.9 & 12.6 & 12.6 & $12.4 \mathrm{~A}$ & $9.6 \mathrm{Ab}$ & 10.9Aab & 11.9Aab & $14.3 \mathrm{Aa}$ & 11.7 \\
\hline & $+\mathrm{P}$ & 10.1 & 8.4 & 9.3 & 8.8 & $9.2 \mathrm{~B}$ & $10.8 \mathrm{Aa}$ & $9.4 \mathrm{Aa}$ & $7.8 \mathrm{Ba}$ & $8.3 \mathrm{Ba}$ & 9.1 \\
\hline & Mean & 11.3 & 10.2 & 10.9 & 10.7 & & 10.2 & 10.1 & 9.9 & 11.3 & \\
\hline \multirow{3}{*}{$\mathrm{Ca}$} & $-\mathrm{P}$ & 1.9 & 3.7 & 5.0 & 3.7 & 3.6 & $2.2 \mathrm{AbA}$ & $2.5 \mathrm{Ab}$ & $4.2 \mathrm{Ba}$ & $2.8 \mathrm{Bb}$ & 2.9 \\
\hline & $+\mathrm{P}$ & 2.2 & 3.6 & 4.5 & 4.7 & 3.7 & $2.4 \mathrm{AcA}$ & $2.5 \mathrm{Ac}$ & $6.0 \mathrm{Aa}$ & $4.0 \mathrm{Ab}$ & 3.8 \\
\hline & Mean & $2.0 \mathrm{~b}$ & $3.6 \mathrm{a}$ & $4.7 \mathrm{a}$ & $4.2 \mathrm{a}$ & & 2.3 & 2.5 & 5.1 & 3.4 & \\
\hline \multirow{3}{*}{$\mathrm{Mg}$} & $-P$ & $1.5 \mathrm{Ab}$ & $2.6 \mathrm{Aa}$ & $1.7 \mathrm{Ab}$ & 2.1Aab & 1.9 & 1.6 & 2.1 & 1.8 & 1.8 & $1.9 \mathrm{~A}$ \\
\hline & $+\mathrm{P}$ & $1.9 \mathrm{Aa}$ & $1.3 \mathrm{Bb}$ & 1.6Aab & $1.9 \mathrm{Aa}$ & 1.7 & 1.6 & 1.5 & 1.6 & 1.8 & $1.6 \mathrm{~B}$ \\
\hline & Mean & 1.7 & 1.9 & 1.7 & 1.9 & & 1.6 & 1.8 & 1.7 & 1.8 & \\
\hline \multirow{3}{*}{$\mathrm{P}$} & $-P$ & $0.6 \mathrm{Ba}$ & $0.4 \mathrm{Ba}$ & $0.8 \mathrm{Aa}$ & $0.6 \mathrm{Ba}$ & 0.6 & $0.7 \mathrm{Bab}$ & $0.3 \mathrm{Bb}$ & $0.8 \mathrm{Aa}$ & $0.6 \mathrm{Bab}$ & 0.6 \\
\hline & $+\mathrm{P}$ & 1.3Aab & 1.1Aab & $0.9 \mathrm{Ab}$ & $1.6 \mathrm{Aa}$ & 1.2 & $1.8 \mathrm{Aa}$ & $0.7 \mathrm{Ac}$ & $1.0 \mathrm{Abc}$ & $1.3 \mathrm{Ab}$ & 1.2 \\
\hline & Mean & 0.9 & 0.7 & 0.8 & 1.1 & & 1.3 & 0.5 & 0.9 & 0.9 & \\
\hline
\end{tabular}

${ }^{1}$ FER - Ferralsol; CAM - Cambisol. Different values for lowercase (soils effect) and uppercase letters (P effect) indicate significant difference by the Tukey test $(\mathrm{p}<0.05)$. Values without letters indicate that there were no significant differences for treatments.

soils), the average $\mathrm{C} / \mathrm{N}$ ratio was 20.6 and 13.8 , respectively. Although $\mathrm{N}$ is easily translocated in the plants according to the increase in their demand (Kabata-Pendias 2011), the leaves analyzed did not show any symptoms of chlorosis, which would indicate high remobilization, probably because there was no limitation due to the $\mathrm{N}$ availability (fertilization with $200 \mathrm{mg} \mathrm{N} \mathrm{kg}^{-1}$ ), with similar $\mathrm{N}$ contents reported by Reissmann et al. (1999). Thus, the low $\mathrm{N}$ contents due to $\mathrm{P}$ fertilization should not have occurred by remobilization of N. In this sense, it is more probable that the decrease of the $\mathrm{N}$ in the leaves occurred due to the increase of the $\mathrm{C}$ fixation and accumulation of plant dry matter.

Similar to that seen for N, a decrease of $\mathrm{K}$ content in the leaves of Clone 1 and Clone 2 (only in CAM2 and CAM3 soils) with phosphate (Table II) confirms the results reported by Santin et al. (2013). However, the results also indicate that the effect of $\mathrm{P}$ fertilization has variation that depends on the interaction between clone and soil. In the present study, the K content in the leaves of yerba mate clones ( 7.8 to $14.3 \mathrm{~g} \mathrm{~kg}^{-1}$ ) had values below 
the range found by Santin et al. (2013), with plants at 120 days ( 9 to $22.5 \mathrm{~g} \mathrm{~kg}^{-1}$ ).

The clones differed in response to the use of $\mathrm{P}$ on foliar Ca (Table II). In general, the lower $\mathrm{Ca}$ contents in leaves of yerba mate clones occurred for FER, accompanying the low availability in the soil (Table I). In Clone 2, FER soil did not differ from CAM1 and CAM3 soil (no P fertilization) (Table II), indicating variations between clones. However, low $\mathrm{Ca}$ contents in leaves for FER soil should have limited the response of yerba mate clones to fertilization in this soil (Figure 1). On the other hand, $\mathrm{P}$ fertilization affected only the Ca content in the leaves of Clone 2 (CAM2 and CAM3), in which elevated contents were found. Pandolfo et al. (2003) found no change in Ca content in yerba mate leaves as a response to phosphate fertilizer, while Santin et al. (2013) found a decrease.

Similar to $\mathrm{Ca}$, the $\mathrm{Mg}$ contents in leaves differ due to P fertilization (Table II). But, unlike Ca, low soil $\mathrm{Mg}$ availability did not determined low contents in leaves of plants grown in FER soil. The $\mathrm{P}$ application caused a decrease in $\mathrm{Mg}$ content in the leaves of yerba mate clones (Clone 1 in CAM1 soil; Clone 2 in the average of the soils), and for Clone 1, the drop in contents was so pronounced that it reversed the difference between CAM1 soil in relation to the others: $>$ content without $\mathrm{P}$ fertilization; < content with $\mathrm{P}$ fertilization (Table II). Evaluating the elemental composition of yerba mate in response phosphate fertilizer, Santin et al. (2013) also reported decreases in $\mathrm{Mg}$ due to fertilization. Under field conditions, Pandolfo et al. (2003) found a decrease in the Mg content in the yerba mate leaves in response to fertilization with poultry litter, even with the application of $\mathrm{Mg}$. This may be an indication that the variations in the $\mathrm{Mg}$ content in the leaves occur due to the increase in production, which dilutes the nutrient levels. However, the effect of $\mathrm{P}$ fertilization on the $\mathrm{Mg}$ content in the leaves depends on the type of soil and the genetic material of yerba mate (Table II), given that the Clone 1, for three soils (FER, CAM2, CAM3) presented no variation of $\mathrm{Mg}$ contents (Table I).

\section{MICRONUTRIENTS}

For micronutrient, a wide variation between clones was observed (Table III), and for Clone 1: there were no effects of treatments for $\mathrm{Fe}$ and $\mathrm{Mo}$; the soil effect on $\mathrm{Zn}, \mathrm{Cu}$ and $\mathrm{Ni}$; the effect of $\mathrm{P}$ application on $\mathrm{Mn}$; and of the interaction only on B. For Clone 2: the interaction between soil and $\mathrm{P}$ application affected $\mathrm{Fe}, \mathrm{Zn}, \mathrm{Cu}, \mathrm{Ni}$ and $\mathrm{B}$ contents; in addition to the soil effect on $\mathrm{Mn}$, and that of $\mathrm{P}$ on Mo.

In CAM2 soil phosphate fertilization increased the Fe content in Clone 2 leaves (61 to $105 \mathrm{mg} \mathrm{kg}^{-1}$ ), while in other conditions there was no change (Table III). In contrast, Santin et al. (2013) found lower Fe content in yerba mate leaves due to fertilization. The $\mathrm{P}$ fertilization can reduce the $\mathrm{Fe}$ content in the leaves due to formation of complexes with $\mathrm{P}\left(\mathrm{FePO}_{4} \cdot \mathrm{nH}_{2} \mathrm{O}\right.$; $\left.\mathrm{Fe}_{3}\left(\mathrm{PO}_{4}\right) \cdot 2 \mathrm{H}_{2} \mathrm{O}\right)$, although this is hindered when $\mathrm{Fe}$ is complexed by organic compounds (KabataPendias 2011). However, plants grown in soil with higher initial $\mathrm{P}$ availability (CAM2) did not present low Fe content in the leaves compared to the other soils. Thus, the relationship between $\mathrm{P}$ and $\mathrm{Fe}$ in yerba mate appears to vary with the interaction among $\mathrm{P}$ dose, the genetic material (differences in Fe acquisition and transport) and the soil (Fe forms and microflora).

In general, the $\mathrm{P}$ fertilization decreased the Mn content in the yerba mate leaves, but with significant effect only for Clone 1 (Table III). However, the fertilizer did not overcome the soil contribution to the Mn content in leaves for CAM2 soil, where foliar content exceeded $1000 \mathrm{mg} \mathrm{kg}^{-1}$ (Clone 1 = $1249 \mathrm{mg} \mathrm{kg}^{-1}$; Clone $2=1033 \mathrm{mg} \mathrm{kg}^{-1}$ ). High Mn content has been observed in the yerba mate leaves, Reissmann et al. (1999) report Mn leaf concentrations ranging from 346 to $3330 \mathrm{mg} \mathrm{kg}$ ${ }^{1}$, in analysis of yerba mate leaves from different 
regions of Paraná. It is noteworthy that despite the high $\mathrm{Mn}$ content in the yerba mate leaves (mature trees and seedlings) symptoms of toxicity do not occur, indicating that the plant has tolerance mechanisms. In industrialized samples (mate or chimarrão infusion) of yerba mate, Pozebon et al. (2015) reported average Mn content between 730 and $1435 \mathrm{mg} \mathrm{kg}^{-1}$, confirming the high content in the final product.

The soil either alone or in interaction with $\mathrm{P}$ application, had a major influence on foliar Zn content (Table III). But the content can be considered normal to high, even in cultivation with soil of low Zn availability, such as FER (Table I), indicating a high capacity for $\mathrm{Zn}$ extraction by the plant, and the contents corroborate values found in leaves in natura (Reissmann et al. 1999) and the final product (Pozebon et al. 2015). However, the results obtained in this study also show that $\mathrm{Zn}$ acquisition capacity may vary among yerba mate genotypes, which came into evidence because of the 8 evaluated conditions ( 4 soil $\times 2$ P treatments), Clone 2 had higher Zn levels in the leaves in 7 of them.

The expected decrease in $\mathrm{Zn}$ content in response to $\mathrm{P}$ fertilization did not occur and contrasting results being obtained: no effect in most cases; increase (CAM1 soil) and decrease (CAM3 soil) in Zn content in Clone 2 leaves (Table III). Santin et al. (2013) found a decrease in the $\mathrm{Zn}$ content of yerba mate leaves as a result of phosphate fertilizer. For many plant species it has been reported that $\mathrm{P}$ may interfere with the absorption and transportation of $\mathrm{Zn}$ (Kabata-Pendias 2011). However, based on this present study it can be said that the interference of $\mathrm{P}$ in the acquisition of $\mathrm{Zn}$ may be less common in yerba mate. In contrast, the increase in $\mathrm{Zn}$ content in Clone 2 leaves (Table III) with phosphate indicates that for a soil with high Zn availability (CAM1) the benefit of $\mathrm{P}$ to plant growth could have stimulated $\mathrm{Zn}$ absorption or transport.
The effect of phosphate fertilizer on the $\mathrm{Cu}$ and $\mathrm{Ni}$ contents was restricted to one soil and one clone (Clone 2 in CAM3 soil), similar to that observed for Zn (Table III). Santin et al. (2013) reported lower $\mathrm{Cu}$ content in the leaves of plants grown under $\mathrm{P}$. In general, the cultivation in CAM1 soil provided the lowest $\mathrm{Cu}$ and $\mathrm{Ni}$ content in the leaves of yerba mate clones, the opposite to what was observed for the $\mathrm{Zn}$ contents. This is probably because of the similarity in the absorption and transport routes of metallic micronutrients, and the high availability of $\mathrm{Zn}$ may have had antagonism with $\mathrm{Cu}$ and $\mathrm{Ni}$ (Kabata-Pendias 2011). However, the interactions among these metallic micronutrients depend on plant species. On the other hand, with young pecan plants (Carya illinoinensis), Wood (2010) did not verify a direct relationship with the $\mathrm{Zn}, \mathrm{Cu}$ and $\mathrm{Ni}$ uptake, but $\mathrm{Zn}$ and $\mathrm{Cu}$ uptake reduced endogenous availability of $\mathrm{Ni}$ in leaves.

For B, it was found that its levels in the leaves were higher for FER and CAM1 soil, precisely the only two soils where the B content in leaves decreased with phosphate (Clone 1 in soils FER and CAM1; Clone 2 the CAM1) (Table III). These results are inconsistent with the available $\mathrm{B}$ content in the evaluated soil (Table I). This indicates that other factors are involved in the dynamics of B in yerba mate or simply that the extractor was not efficient to have a direct relation with the leaf contents. Furthermore, despite the lower B content in yerba mate leaves having been observed in CAM2 soil (15 to $29 \mathrm{mg} \mathrm{B} \mathrm{kg}^{-1}$ ) and CAM3 (8 to $\left.13 \mathrm{mg} \mathrm{B} \mathrm{kg}{ }^{-1}\right)$, low plant growth only occurred in CAM3 (Figure 1). Thus, whereas in CAM2 soil there was high plant growth, it is possible that for plants grown in soil CAM3, B was a limiting factor to the growth of yerba mate. Reissmann et al. (1999) report B levels in leaf of yerba mate with up to one year of age ranging from 20 to $23 \mathrm{mg} \mathrm{kg}^{-1}$.

The $P$ fertilization decreased Mo content only in the Clone 2 leaves (Table III). In general, it is known that $\mathrm{S}$ has great interference in Mo absorption, and 
TABLE III

The Fe, Mn, $\mathrm{Zn}, \mathrm{Cu}, \mathrm{Ni}, \mathrm{B}$ and Mo contents $\left(\mathrm{mg} \mathrm{kg}^{-1}\right)$ in leaves of yerba mate clones in response to $\mathrm{P}$ fertilization, at 210 days after installation of the experiments ${ }^{1}$.

\begin{tabular}{|c|c|c|c|c|c|c|c|c|c|c|c|}
\hline & & \multicolumn{4}{|c|}{ Clone 1} & \multirow[b]{2}{*}{ Mean } & \multicolumn{5}{|c|}{ Clone 2} \\
\hline & & FER & CAM1 & CAM2 & CAM3 & & FER & CAM1 & CAM2 & CAM3 & Mean \\
\hline \multirow{3}{*}{$\mathrm{Fe}$} & $-\mathrm{P}$ & 64 & 82 & 72 & 75 & 73 & $63 \mathrm{Aa}$ & $83 \mathrm{Aa}$ & $61 \mathrm{Ba}$ & $78 \mathrm{Aa}$ & 71 \\
\hline & $+\mathrm{P}$ & 68 & 77 & 74 & 75 & 74 & 76Aab & $55 \mathrm{Ab}$ & $105 \mathrm{Aa}$ & 78Aab & 74 \\
\hline & Mean & 66 & 79 & 73 & 75 & & 61 & 68 & 83 & 77 & \\
\hline \multirow{3}{*}{$\mathrm{Mn}$} & $-\mathrm{P}$ & 130 & 521 & 1329 & 477 & $614 \mathrm{~A}$ & 145 & 418 & 1141 & 443 & 536 \\
\hline & $+\mathrm{P}$ & 162 & 273 & 1169 & 339 & 485B & 129 & 347 & 926 & 349 & 437 \\
\hline & Mean & $145 \mathrm{c}$ & $346 b$ & $1249 \mathrm{a}$ & $408 b$ & & $136 b$ & $382 b$ & $1033 a$ & $395 b$ & \\
\hline \multirow{3}{*}{$\mathrm{Zn}$} & $-P$ & 27 & 81 & 29 & 57 & 48 & $46 \mathrm{Aa}$ & $76 \mathrm{Ba}$ & $46 \mathrm{Aa}$ & 79Aa & 61 \\
\hline & $+\mathrm{P}$ & 29 & 83 & 22 & 26 & 40 & $64 \mathrm{Ab}$ & $133 \mathrm{Aa}$ & $50 \mathrm{Ab}$ & $46 \mathrm{Bb}$ & 73 \\
\hline & Mean & $28 \mathrm{~b}$ & $82 a$ & $25 b$ & $41 b$ & & 55 & 104 & 48 & 62 & \\
\hline \multirow{3}{*}{$\mathrm{Cu}$} & $-\mathrm{P}$ & 4.1 & 3.5 & 4.5 & 6.3 & 4.6 & $3.0 \mathrm{Ab}$ & $2.9 \mathrm{Ab}$ & $4.9 \mathrm{Ab}$ & 7.1Aa & 4.5 \\
\hline & $+\mathrm{P}$ & 3.5 & 2.5 & 5.3 & 4.8 & 4.0 & 4.1Aa & $2.1 \mathrm{Ab}$ & 4.7Aa & $4.4 \mathrm{Ba}$ & 3.8 \\
\hline & Mean & $3.8 \mathrm{bc}$ & $3.0 \mathrm{c}$ & $4.9 \mathrm{ab}$ & $5.5 \mathrm{a}$ & & 3.6 & 2.4 & 4.8 & 5.7 & \\
\hline \multirow{3}{*}{$\mathrm{Ni}$} & $-P$ & 1.2 & 0.4 & 0.9 & 1.1 & 0.9 & $0.5 \mathrm{Ab}$ & $0.3 \mathrm{Ab}$ & 0.9Aab & $1.5 \mathrm{Aa}$ & 0.8 \\
\hline & $+\mathrm{P}$ & 1.2 & 0.4 & 0.9 & 1.0 & 0.9 & $0.7 \mathrm{Aab}$ & $0.3 \mathrm{Ab}$ & 1.1Aa & $0.9 \mathrm{Ba}$ & 0.7 \\
\hline & Mean & $1.2 \mathrm{a}$ & $0.4 \mathrm{~b}$ & $0.9 \mathrm{ab}$ & $1.1 \mathrm{ab}$ & & 0.5 & 0.3 & 1.0 & 1.2 & \\
\hline \multirow{3}{*}{ B } & $-P$ & $48 \mathrm{Aa}$ & $66 \mathrm{Aa}$ & $19 \mathrm{Ab}$ & $10 \mathrm{Ab}$ & 36 & $43 \mathrm{Ab}$ & $67 \mathrm{Aa}$ & 29Ac & $13 \mathrm{Ad}$ & 38 \\
\hline & $+\mathrm{P}$ & $34 \mathrm{Ba}$ & $34 \mathrm{Ba}$ & $15 \mathrm{Ab}$ & $8 \mathrm{Ab}$ & 22 & $36 \mathrm{Aa}$ & $39 \mathrm{Ba}$ & $21 \mathrm{Ab}$ & $11 \mathrm{Ab}$ & 27 \\
\hline & Mean & 41 & 50 & 17 & 9 & & 39 & 53 & 25 & 12 & \\
\hline \multirow{3}{*}{ Mo } & $-\mathrm{P}$ & 0.10 & 0.17 & 0.35 & 0.29 & 0.23 & 0.10 & 0.37 & 0.26 & 0.09 & $0.20 \mathrm{~A}$ \\
\hline & $+\mathrm{P}$ & 0.12 & 0.09 & 0.11 & 0.10 & 0.11 & 0.10 & 0.15 & 0.08 & 0.09 & $0.10 \mathrm{~B}$ \\
\hline & Mean & 0.11 & 0.13 & 0.22 & 0.19 & & 0.10 & 0.26 & 0.17 & 0.09 & \\
\hline
\end{tabular}

${ }^{1}$ FER - Ferralsol; CAM - Cambisol. Different values for lowercase (soils effect) and uppercase letters (P effect) indicate significant difference by the Tukey test $(\mathrm{p}<0.05)$. Values without letters indicate that there were no significant differences for treatments.

variable results have been found for $\mathrm{P}$ (Kaiser et al. 2005). However, in soils with high acidity, Mo availability is extremely low, as observed in this present study (Table I), which may have favored the antagonistic effect of $\mathrm{P}$ fertilization on Mo in leaves. In addition, this effect should be added to the fact that the $\mathrm{P}$ had significantly increased yerba mate growth (Figure 1), favoring the dilution of Mo content in Clone 2 leaves.

\section{POTENTIALLY TOXIC ELEMENTS}

For the trace elements $\mathrm{Al}, \mathrm{Ba}, \mathrm{Pb}, \mathrm{Cd}, \mathrm{Cr}$, and $\mathrm{V}$ the soil presented an influence on leaf content. The effect of $\mathrm{P}$ fertilization resulted in $\mathrm{Al}$ change in Clone 1, V in Clone 2, and via interaction for $\mathrm{Ba}$, $\mathrm{Pb}$ and $\mathrm{Cd}$ in both clones (Table IV).

The absence of $\mathrm{P}$ fertilization effect on the $\mathrm{Al}$ content for Clone 2 leaves (Table IV) corroborate with results reported by Santin et al. (2013). However, the $\mathrm{Al}$ content decrease in Clone 1 leaves in response to $\mathrm{P}$ fertilization (Table IV) indicates that there are variations according to the yerba mate clone. Regarding the Al contents registered (270 to $589 \mathrm{mg} \mathrm{kg}^{-1}$ ), they can be considered high in comparison to leaves of most crops, such as in maize (Domingues et al. 2016), and even in the Brazilian pine [native in same region of yerba mate] (Barbosa et al. 2017), but have been observed in other studies with yerba mate (Reissmann et al. 1999, Pozebon et al. 2015). Although there was an effect of soil on Al in the plant, the values in the plant did not follow the nine-fold variation between lowest and highest value of $\mathrm{Al}$ in the soil. The highest growth was achieved in the plant with higher $\mathrm{Al}$ content in the leaves, indicating, as with 
TABLE IV

The Al, Ba, $\mathrm{Pb}, \mathrm{Cd}, \mathrm{Cr}$ and $\mathrm{V}$ contents $\left(\mathrm{mg} \mathrm{kg}^{-1}\right)$ in leaves of yerba mate clones in response to $\mathrm{P}$ fertilization, at 210 days after installation of the experiments ${ }^{1}$.

\begin{tabular}{|c|c|c|c|c|c|c|c|c|c|c|c|}
\hline & \multicolumn{4}{|c|}{ Clone 1} & \multirow[b]{2}{*}{ Mean } & \multicolumn{5}{|c|}{ Clone 2} \\
\hline & & FER & CAM1 & CAM2 & CAM3 & & FER & CAM1 & CAM2 & CAM3 & Mean \\
\hline \multirow{3}{*}{$\mathrm{Al}$} & $-\mathrm{P}$ & 453 & 478 & 589 & 495 & $503 \mathrm{~A}$ & 376 & 371 & 483 & 382 & 403 \\
\hline & $+\mathrm{P}$ & 374 & 408 & 532 & 451 & $441 \mathrm{~B}$ & 402 & 270 & 456 & 416 & 386 \\
\hline & Mean & $413 b$ & $443 b$ & $560 \mathrm{a}$ & $473 b$ & & $389 a b$ & $320 \mathrm{~b}$ & $470 \mathrm{a}$ & 399ab & \\
\hline \multirow{3}{*}{$\mathrm{Ba}$} & $-\mathrm{P}$ & $17 \mathrm{Ac}$ & 31Bbc & 47Aa & $33 \mathrm{Bab}$ & 32 & $23 \mathrm{Aab}$ & $19 \mathrm{Ab}$ & $31 \mathrm{Ba}$ & $21 \mathrm{Bab}$ & 23 \\
\hline & $+\mathrm{P}$ & $27 \mathrm{Ac}$ & $43 \mathrm{Ab}$ & $52 \mathrm{Aab}$ & $61 \mathrm{Aa}$ & 46 & $13 \mathrm{Bb}$ & $21 \mathrm{Ab}$ & 49Aa & $43 \mathrm{Aa}$ & 32 \\
\hline & Mean & 22 & 37 & 49 & 46 & & 18 & 20 & 40 & 32 & \\
\hline \multirow{3}{*}{$\mathrm{Pb}$} & $-\mathrm{P}$ & $0.23 \mathrm{Ab}$ & 0.69Aa & $0.64 \mathrm{Aa}$ & $0.64 \mathrm{Aa}$ & 0.54 & $0.38 \mathrm{Aab}$ & $0.47 \mathrm{Aa}$ & $0.50 \mathrm{Aa}$ & $0.26 \mathrm{Bb}$ & 0.40 \\
\hline & $+\mathrm{P}$ & $0.41 \mathrm{Aab}$ & $0.32 \mathrm{Bb}$ & $0.64 \mathrm{Aa}$ & $0.40 \mathrm{Bab}$ & 0.44 & $0.22 \mathrm{Bb}$ & $0.35 \mathrm{Ab}$ & $0.56 \mathrm{Aa}$ & $0.42 \mathrm{Aab}$ & 0.38 \\
\hline & Mean & 0.31 & 0.50 & 0.64 & 0.51 & & 0.30 & 0.41 & 0.53 & 0.33 & \\
\hline \multirow{3}{*}{$\mathrm{Cd}$} & $-P$ & $0.07 \mathrm{Ac}$ & $0.36 \mathrm{Aa}$ & $0.21 \mathrm{Ab}$ & $0.37 \mathrm{Aa}$ & 0.25 & $0.11 \mathrm{Ab}$ & $0.28 \mathrm{Aa}$ & $0.20 \mathrm{Aab}$ & $0.24 \mathrm{Aa}$ & 0.20 \\
\hline & $+\mathrm{P}$ & $0.09 \mathrm{Ab}$ & $0.11 \mathrm{Bb}$ & $0.18 \mathrm{Aab}$ & $0.24 \mathrm{Ba}$ & 0.15 & $0.07 \mathrm{Ac}$ & $0.10 \mathrm{Bbc}$ & $0.20 \mathrm{Aab}$ & $0.23 \mathrm{Aa}$ & 0.15 \\
\hline & Mean & 0.08 & 0.23 & 0.20 & 0.30 & & 0.09 & 0.19 & 0.20 & 0.23 & \\
\hline \multirow{3}{*}{$\mathrm{Cr}$} & $-P$ & 0.39 & 0.35 & 0.73 & 0.37 & 0.46 & 0.35 & 0.38 & 0.80 & 0.59 & 0.53 \\
\hline & $+\mathrm{P}$ & 0.34 & 0.30 & 0.66 & 0.39 & 0.42 & 0.31 & 0.32 & 0.72 & 0.47 & 0.45 \\
\hline & Mean & $0.36 \mathrm{~b}$ & $0.32 \mathrm{~b}$ & $0.69 a$ & $0.38 \mathrm{~b}$ & & $0.33 b$ & $0.35 \mathrm{~b}$ & $0.76 \mathrm{a}$ & $0.53 \mathrm{ab}$ & \\
\hline \multirow{3}{*}{ V } & $-\mathrm{P}$ & 0.08 & 0.12 & 0.07 & 0.10 & 0.09 & $0.13 \mathrm{Aa}$ & $0.14 \mathrm{Aa}$ & $0.07 \mathrm{Ba}$ & $0.10 \mathrm{Aa}$ & 0.11 \\
\hline & $+\mathrm{P}$ & 0.10 & 0.10 & 0.07 & 0.07 & 0.09 & 0.11Aab & 0.08Aab & $0.16 \mathrm{Aa}$ & $0.07 \mathrm{Ab}$ & 0.10 \\
\hline & Mean & $0.09 \mathrm{ab}$ & $0.11 \mathrm{a}$ & $0.07 \mathrm{~b}$ & $0.08 \mathrm{ab}$ & & 0.12 & 0.12 & 0.12 & 0.8 & \\
\hline
\end{tabular}

${ }^{1}$ FER - Ferralsol; CAM - Cambisol. Different values for lowercase (soils effect) and uppercase letters (P effect) indicate significant difference by the Tukey test $(\mathrm{p}<0.05)$. Values without letters indicate that there were no significant differences for treatments.

Mn, that the content observed seems not to be limiting the yerba mate plant growth.

The increase of $\mathrm{Ba}$ content in the leaves of yerba mate clones in response to $\mathrm{P}$ fertilization (Clone 1, CAM1 and CAM3 soils; Clone 2, CAM2 and CAM3 soils) (Table IV) indicates that the growth stimulation caused by $\mathrm{P}$ in these conditions may have favored the acquisition of $\mathrm{Ba}$. In addition to $\mathrm{Ba}$, the only alkaline earth element which presented high content in yerba mate leaves by $\mathrm{P}$ fertilization (Clone 2, CAM2 and CAM3 soils) was Ca (Table II), probably due to the similarity of physical and chemical characteristics and transport in plants as discussed by White (2001). However, for FER soil the Ba levels in Clone 2 leaves were decreased with $\mathrm{P}$ fertilization (Table IV), which may be due to the low availability of $\mathrm{Ba}$ in that soil. For the differences among soils: in the absence of $\mathrm{P}$ fertilizer, the $\mathrm{Ba}$ content in the leaves of the clones was superior to that in the CAM2 soil; and with phosphorus fertilization, the levels were higher in soil CAM3 (Clone 1) and the CAM2 and CAM3 soil (Clone 2) (Table IV), both soils with greater availability of $\mathrm{Ba}$ than the other soils (Table I).

As shown above, the $\mathrm{Pb}$ content varied with the soil and P fertilizer in half of the evaluated conditions (Table IV). Of the four conditions where $\mathrm{P}$ fertilization resulted in a change, three presented a content decrease and one an increase. Furthermore, the $\mathrm{Pb}$ content in the leaves also varied between clones, for example: in the CAM3 soil the $\mathrm{P}$ application resulted in a decrease and increase for Clone 1 and 2, respectively. Because of this, is not possible make a generalization about the response to $\mathrm{P}$ fertilization under controlled conditions. For CAM1 and CAM3 soils the effect of $\mathrm{P}$ fertilizer enabled the $\mathrm{Pb}$ content in the Clone 1 leaves to fall below the level of $0.6 \mathrm{mg}$ $\mathrm{kg}^{-1}$, contrary to what was found in the absence of fertilizer. On the other hand, in Clone 2, $\mathrm{P}$ 
fertilization reduced the $\mathrm{Pb}$ content in the leaves for one soil (FER) and increased in another (CAM3), although in none of these conditions was the level of $0.6 \mathrm{mg} \mathrm{kg}^{-1}$ exceeded. The value of $0.6 \mathrm{mg} \mathrm{kg}^{-1}$ is important; it is adopted as the maximum permitted by the MERCOSUL legislation in yerba mate and tea products (Anvisa 2013). However, all values are much lower compared to the limit $\left(5 \mathrm{mg} \mathrm{kg}^{-1}\right)$ established for the tea in China (GB 2762 2012).

In three (Clone 1 in CAM1 and CAM3 soils; Clone 2 in CAM1 soil) of the eight conditions tested, the use of $\mathrm{P}$ determined a decrease in the $\mathrm{Cd}$ content in the leaves, thus, the $\mathrm{P}$ was beneficial (Table IV). However, it is important to consider that in this study the P source used was a pure analytical product, certainly with a low Cd content, since fertilization with phosphate rock fertilizer has resulted, in some cases, in an increase in leaf tissue Cd (Kabata-Pendias 2011). In the absence of phosphate fertilizer, the highest $\mathrm{Cd}$ content in the leaves of yerba mate clones occurred in CAM1 and CAM3 soils, indicating that plants with low dry matter showed higher $\mathrm{Cd}$ levels. In contrast, in the presence of $\mathrm{P}$ fertilizer, the $\mathrm{Cd}$ content in the leaves of yerba mate clones followed the same descending sequence that was verified for the availability of $\mathrm{Cd}$ in soil: CAM3, CAM2, CAM1 and FER (Table I; Table III). That is, very weathered soil and with poor parent material, like FER, certainly has less Cd availability. For yerba mate, works in the literature analyzing $\mathrm{Cd}$ availability in soil and leaves are scarce. Differing from $\mathrm{Pb}$, all $\mathrm{Cd}$ levels were below $0.4 \mathrm{mg} \mathrm{kg}^{-1}$ (maximum permitted by the MERCOSUL legislation) (Anvisa 2013).

The $\mathrm{Cr}$ content in leaves of yerba mate clones was higher in plants grown in soil CAM2 (soil with lower availability of the element) (Table IV). The use of Mehlich 1 extractant to evaluate the $\mathrm{Cr}$ availability in the soil was not efficient due to the influence of oxidation-reduction chemical reactions governing the $\mathrm{Cr}$ forms and thus its availability for plants. In soils, transformation of Cr(III) (low mobility in plants) to $\mathrm{Cr}(\mathrm{VI})$ (high mobility in plants) is promoted by the presence of Mn oxides which act as Cr oxidizing agents (Oliveira 2012). The CAM2 soil had poor crystalline Mn forms $\left(0.175 \mathrm{~g} \mathrm{~kg}^{-1}\right) 11$ to 175 times higher than other soils and was the only soil in which crystalline $\mathrm{Mn}$ forms were detected $\left(0.10 \mathrm{~g} \mathrm{~kg}^{-1}\right)$, probably with more $\mathrm{Mn}$ oxides. In other side, in the CAM2 soil the yerba mate plants also showed higher growth. However, this factor should not have been important for the absorption and transport of $\mathrm{Cr}$, given that there was no change due to $\mathrm{P}$ fertilization, which promoted plant growth in all soils.

Similar to Fe, the V content was elevated by $\mathrm{P}$ fertilization only in Clone 2 in CAM2 soil (Table IV). In contrast, although there were variations among the soils, they were not dependent on the availability of initial V availability in the soil (Table I). In the soil solution $\mathrm{V}$ is found in its cationic form as well as anionic, whereas in acidic soils, there is predominance of the vanadyl $\left(\mathrm{VO}^{2+}\right)$ ion which is similar to $\mathrm{Fe}^{2+}$, due to the high affinity for organic compounds and preferably being absorbed by plants (Kabata-Pendias 2011). In addition, Fe transport from the roots to the shoots occurs in the complexed form, especially with citrate (Kobayashi and Nishizawa 2012). Thus, considering that the formation of a V-citrate complex also occurs (Crans et al. 2004), it is possible that Fe and V share one or more ways of transport from the roots to shoots.

Arsenic and Co were detected in only $42 \%$ and $57 \%$ of the samples, respectively. Considering those samples with a reading, the As varied between 0.003 and $0.0250 \mathrm{mg} \mathrm{kg}^{-1}$, and the Co varied between 0.001 and $0.180 \mathrm{mg} \mathrm{kg}^{-1}$. According to legislation covering the MERCOSUL, the As content must be less than $0.6 \mathrm{mg} \mathrm{kg}^{-1}$ in yerba mate and tea products (Anvisa 2013). 


\section{INTERACTIONS BETWEEN ELEMENTS}

The Pearson correlation results between growth attributes and elemental composition are shown in Figure 2. The $\mathrm{P}$ showed low correlation $(\mathrm{r}=0.30$ [Clone 2]) with the dry matter, probably due to divergent results among soils (Figure 1; Table II). This fact confirms the difficulty to consider only $\mathrm{P}$ to assess the nutritional status of $\mathrm{P}$. The inverse relationship between the dry matter and height according to $\mathrm{N}$ content $(\mathrm{r}=-0.76$ [Clone 1], $\mathrm{r}=$ - 0.67 [Clone 2]) occur probably because of the dilution effect. Moreover, based on the negative correlations between $\mathrm{C}$ and $\mathrm{N}$ in the leaves (Figure 2 ), it is possible that the increase of $\mathrm{C}$ contents in the leaves due to phosphate fertilization (Table II) contributed to the dilution effect of $\mathrm{N}$ contents. Considering only the elements, positive correlations between $\mathrm{C}$ x P, Ca x Ba, Fe x V and, Mn x Cr confirm some of the results discussed above. Positive correlations were also found between various other metals, for example, the non-essential elements ( $\mathrm{Al}, \mathrm{Ba}$ and $\mathrm{Cd}$ ) and essential elements ( $\mathrm{Ca}, \mathrm{Mg}, \mathrm{Fe}$ and $\mathrm{Mn}$ ). Zinc, $\mathrm{Fe}$ and $\mathrm{Mn}$ transporters influenced the transport of $\mathrm{Cd}$, for example, NRAMP, IRT and ZIP transporters and, Ca channels may also be related to the entry of $\mathrm{Cd}$ uptake in plants (Clemens 2006). Lead also correlated with $\mathrm{Ca}, \mathrm{Mg}, \mathrm{Fe}, \mathrm{Mn}$, $\mathrm{Al}$, and $\mathrm{Ba}$ for one or both clones, but not related to the $\mathrm{Cd}$ (Figure 2), indicating acquisition or transport would be differentiated between $\mathrm{Cd}$ and $\mathrm{Pb}$, although $\mathrm{Pb}$ could also be absorbed through ion channels and carrier proteins (Pourrut et al. 2011). The clones varied more when negative correlations were considered, since clone 1 and clone 2 had, respectively, eight and 15 negative correlations and, clone 1 and clone 2 presented four $(\mathrm{Bax} \mathrm{N}$; $\mathrm{Ba}$ x B; C x Cd; $\mathrm{Mn}$ x V) and six negative correlations (Al x Zn; Cd x P; Ba x N; Ba x K; Ba x Zn; Ba $\mathrm{x} B$ ) between essential elements and nonessential elements.

According to the PCA, there is distinction among the four samples of acidic soils with a PC1 and PC2 of $40.8 \%$ and $31.1 \%$ for Clone 1 and, $38.8 \%$ and $31.8 \%$ for Clone 2, respectively (Figure 3). The results reveal that $\mathrm{Mn}$ has its leaf content in the two clones highly related with the highest availability of the element in the soil due to crystalline and poor crystalline forms. This
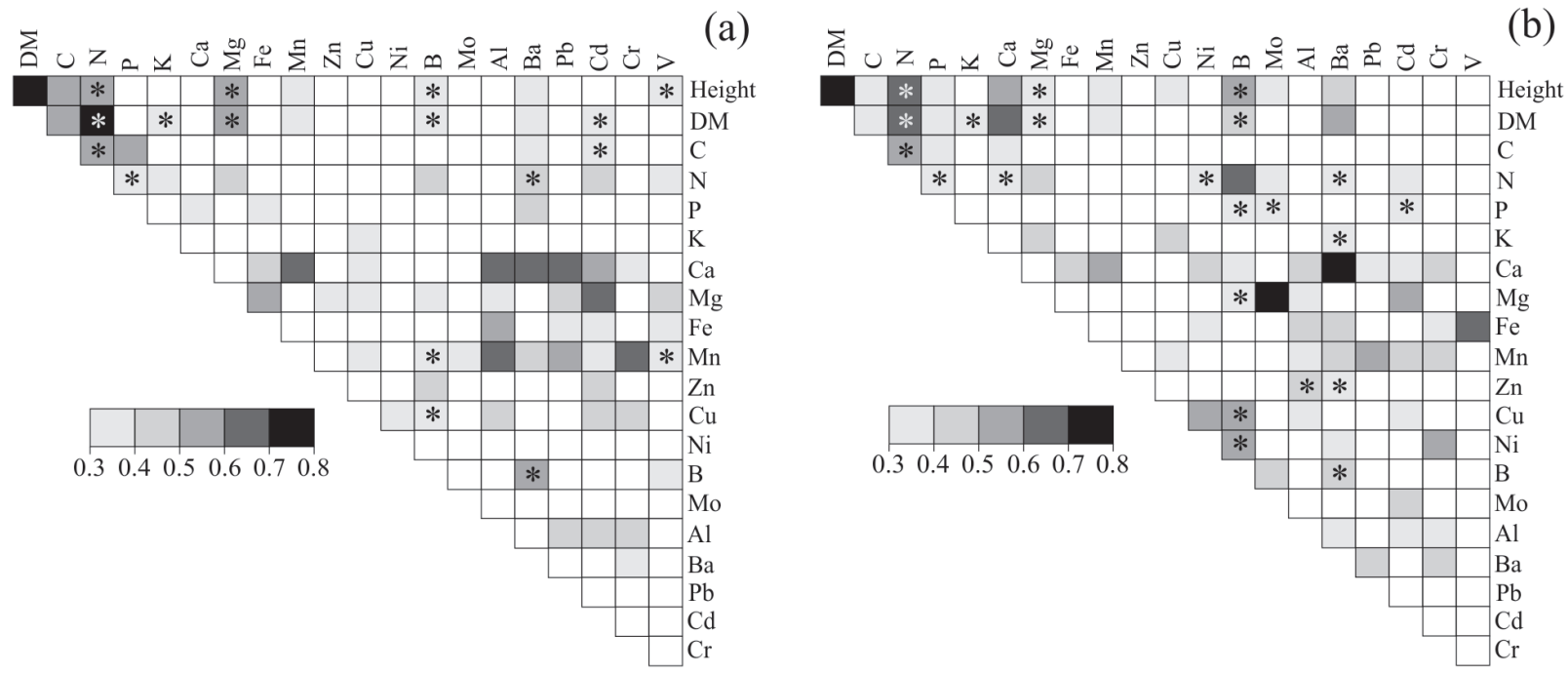

Figure 2 - Correlograms of growth attributes and elements in leaves of yerba mate clones $(\mathbf{a}=$ Clone $1 ; \mathbf{b}=2 \mathrm{Clone})$. Where: DM $=$ aerial part dry matter. Squares with colors indicate significant correlation $(p<0.05)$, while white squares indicate that there were no significant correlations. Asterisks indicate negative correlations. 

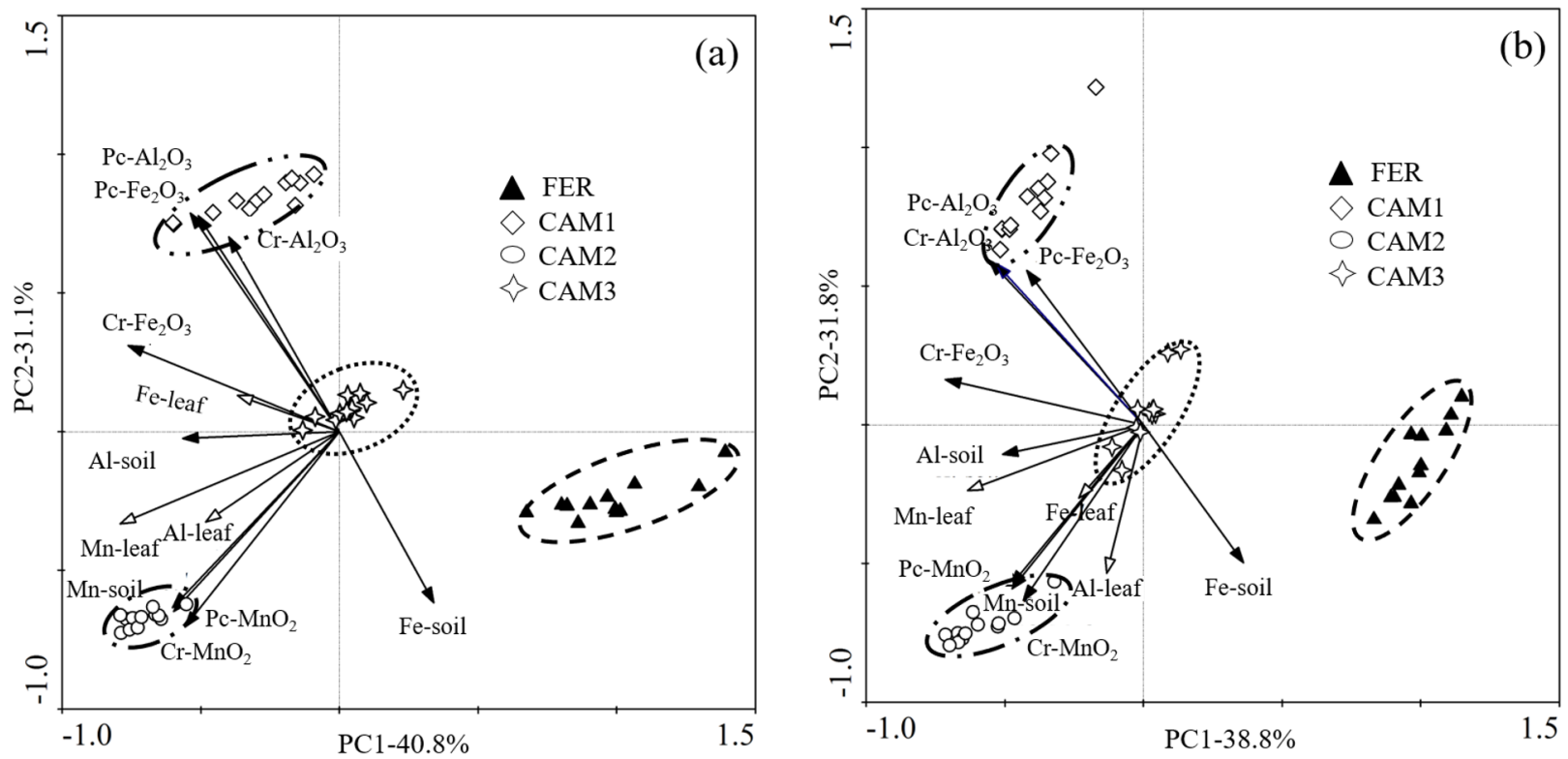

Figure 3 - Principal component analysis of Mn, Fe and Al in the leaves of clones (a: Clone 1, b: Clone 2) of yerba mate and Mn, Fe and Al (soil: available; Pc: poor crystalline forms; Cr: crystalline forms) in four acid soils. FER - Ferralsol; CAM - Cambisol. PC: principal component.

fact was evident in the CAM2 soil where the leaf content exceeded $1000 \mathrm{mg} \mathrm{kg}^{-1}$ (Clone $1=1249$ $\mathrm{mg} \mathrm{kg}^{-1}$; Clone $2=1033 \mathrm{mg} \mathrm{kg}^{-1}$ ) (Table III) due to the high Mn content of this soil, in the available form (available $\mathrm{Mn}=48.7 \mathrm{mg} \mathrm{dm}^{-3}$ ), as well as the poor crystalline $\left(\mathrm{Pc}-\mathrm{MnO}_{2}=0.175 \mathrm{~g} \mathrm{~kg}^{-1}\right)$ and crystalline forms $\left(\mathrm{Cr}-\mathrm{MnO}_{2}=0.10 \mathrm{~g} \mathrm{~kg}^{-1}\right)$ (Table I). Thus, considering that in leaf samples and yerba mate industrialized products similar or higher Mn values have been verified (Reissmann et al. 1999, Pozebon et al. 2015), the results indicate that most of yerba mate has been grown on acid soils with high Mn.

Furthermore, the PCA (Figure 3) revealed that the Al available soil had effect in leaves contents, particularly Clone 1, although much less expressive than observed for Mn. This was because in following FER-CAM1-CAM2-CAM3 soils, the $\mathrm{Al}$ available in the soil (Table I) and the Al leaf levels in Clone 1 (Table IV) were directly related to CAM2, Al content in CAM3 decreasing in leaves despite high availability in the soil. Reissmann et al. (1999), with wide range of yerba mate samples (seven regions of Paraná), found no relationship between the availability of the element in the soil and in the leaves. In parallel, it was possible to distinguish the clayey soils from sandy (FER soil) (Figure 3) because there are lower levels of $\mathrm{Mn}, \mathrm{Fe}$ or $\mathrm{Al}$ oxides in the sandy, and low available $\mathrm{Mn}$ and Al content, which provided lower levels of these elements in the plant leaves.

\section{GENERAL VARIATION FOR CLONES}

Considering the aerial part dry matter and the 19 elements detected, it was found that only the content of four elements in leaves varied between the yerba mate clones (Figure 4). In Clone 1 higher contents of $\mathrm{Ba}(40 \%) \mathrm{Pb}(26 \%)$, and $\mathrm{Al}(20 \%)$ were recorded and lower contents of $\mathrm{Zn}(33 \%)$ compared to Clone 2. The Clone 2 leaves would be more interesting in terms of human nutrition, because they had higher levels of a nutrient ( $\mathrm{Zn}$ ) and lower levels of non-essential elements. Based on nutritional value estimates of yerba mate leaves 
made by Barbosa et al. (2015), the present study verifies the intake of infusion prepared with Clone 2 leaves contribute up to $11.5 \%$ of the daily $\mathrm{Zn}$ requirements (in adults) whereas the contribution by Clone 1 was $7.6 \%$.

\section{CONCLUSIONS}

The P fertilization showed great positive effect on the growth of yerba mate clones, which indicates the importance of $\mathrm{P}$ to the initial growth phase. However, the growth increment is lower in soil with higher initial availability of $\mathrm{P}$ or with some nutritional limitation. The $\mathrm{P}$ fertilization changes the elemental composition of leaves, although the effect can vary according to soil type and clone. In general, the $\mathrm{P}$ fertilization exerted different effects on the elemental composition of the leaves: decrease/null ( $\mathrm{N}, \mathrm{K}, \mathrm{Mg}, \mathrm{Mn}, \mathrm{Cu}, \mathrm{Ni}, \mathrm{B}$, $\mathrm{Mo}, \mathrm{Al}, \mathrm{Cd})$; increase/null (C/N, C, P, Ca, Fe, V); increase/decrease/null ( $\mathrm{Zn}, \mathrm{Ba}, \mathrm{Pb})$ and; null $(\mathrm{Cr})$. Nevertheless, it is worth noting that leaf $\mathrm{P}$ content present low correlation with yerba mate growth, being not a good plant growth indicator. Regarding the soil, all elements determined in the yerba mate leaves, except Mo, showed divergence between soils. However, the element with the highest expression was $\mathrm{Mn}$, the soil factor, compared to $\mathrm{P}$ fertilizer and clones, contributing most to determine whether the Mn leaf accumulation is higher than $1000 \mathrm{mg} \mathrm{kg}^{-1}$. In addition to soil acidity, Mn accumulation in leaves was dependent on the availability of this element in the soil, combined with poor crystalline and crystalline Mn forms. It became clear the influence of genotypic variation of yerba mate, given that the clones varied with respect to $\mathrm{Ba}, \mathrm{Pb}, \mathrm{Al}$ (non-essential/potentially toxic) and $\mathrm{Zn}$ (essential) in leaves.

\section{ACKNOWLEDGMENTS}

The authors thank the Coordenação de Aperfeiçoamento de Pessoal de Nível Superior

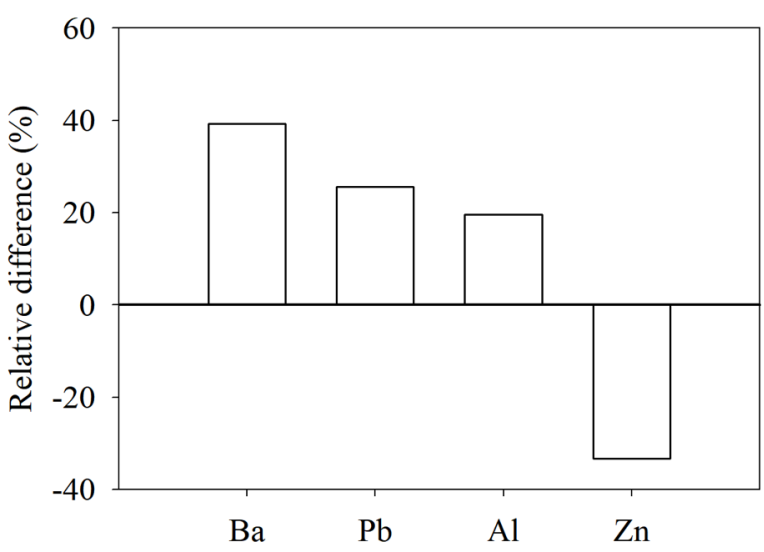

Figure 4 - Relative difference of $\mathrm{Ba}, \mathrm{Pb}, \mathrm{Al}$ and $\mathrm{Zn}$ content in Clone 1 compared to Clone $2(\mathrm{p}<0.05)$.

(CAPES) and the Fundação Araucária de Apoio ao Desenvolvimento Científico e Tecnológico do Estado do Paraná (FA), for supporting and sponsoring this research.

\section{REFERENCES}

ANVISA - AGÊNCIA NACIONAL DE VIGILÂNCIA SANITÁRIA. 2013. Diário Oficial Da União. Resolução - RDC no- 42, de 29 de agosto de 2013.

BARBOSA JZ, ZAMBON LM, MOTTA ACV AND WENDLING I. 2015. Composition, hot-water solubility of elements and nutritional value of fruits and leaves of yerba-mate. Cienc Agrotec 39: 593-603.

BARBOSA JZ, CONSTANTINO V, ZANETTE F, MOTTA ACV AND PRIOR SA. 2017. Soil fertility affects elemental distribution in needles of the conifer Araucaria angustifolia: A microanalytical study. Cerne 23: 257-266.

CARDOZO JUNIOR EL AND MORAND C. 2016. Interest of mate (Ilex paraguariensis A. St.-Hil.) as a new natural functional food to preserve human cardiovascular health A review. J Funct Foods 21: 440-454.

CECONI DE, POLETTO I, LOVATO T AND MUNIZ MFB. 2007. Exigência nutricional de mudas de erva-mate (Ilex paraguariensis A. St.-Hil.) à adubação fosfatada. Cienc Florest 17: 25-32.

CLEMENS S. 2006. Toxic metal accumulation, responses to exposure and mechanisms of tolerance in plants. Biochimie 88: 1707-1719.

CRANS DC, SMEE JJ, GAIDAMAUSKAS E AND YANG L. 2004. The chemistry and biochemistry of vanadium and the biological activities exerted by vanadium compounds. Chem Rev 104: 849-902. 
DOMINGUES CRS, BARBOSA JZ, CONSALTER R, SANTOS, M, ADAM WM AND MOTTA ACV. 2016. Influence of zinc deficiency on the mineral composition of maize plants in contrasting soils. Biosci J 32: 1234-1245.

ELANCHEZHIAN R, KRISHNAPRIYA V, PANDEY R, RAO AS AND ABROL YP. 2015. Physiological and molecular approaches for improving phosphorus uptake efficiency of crops. Curr Sci 108: 1271-1279.

GB 2762. 2012. Maximum levels of contaminants in foods. The national standard of the people's republic of China.

GÉRARD F. 2016. Clays minerals, iron/aluminum oxides, and their contribution to phosphate sorption in soils - A myth revisited. Geoderma 262: 213-226.

IUSS WORKING GROUP WRB. 2015. World Reference Base for Soil Resources 2014, update 2015: International soil classification system for naming soils and creating legends for soil maps. World Soil Resources Reports No. 106. Rome: FAO, $192 \mathrm{p}$

KABATA-PENDIAS A. 2011. Trace elements in soils and plants, $4^{\text {th }}$ ed., London, New York: Taylor \& Francis, 505 p.

KAISER BN, GRIDLEY KL, BRADY JN, PHILLIPS T AND TYERMAN SD. 2005. The role of molybdenum in agricultural plant production. Ann Bot 96: 745-754.

KOBAYASHI T AND NISHIZAWA NK. 2012. Iron uptake, translocation, and regulation in higher plants. Annu Rev Plant Biol 63: 131-152.

LIN ZH, CHEN LS, CHEN RB, ZHANG FZ, JIANG HX AND TANG N. 2009. $\mathrm{CO}_{2}$ assimilation, ribulose-1,5biphosphate carboxylase/oxygenase, carbohydrates and photosynthetic electron transport probed by the JIP-test, of tea leaves in response to phosphorus supply. BMC Plant Biol 9: 43.

MARTINS APL AND REISSMANN CB. 2007. Material vegetal e as rotinas laboratoriais nos procedimentos químico analíticos. Scientia Agraria 8: 1-17.
OLIVEIRA H. 2012. Chromium as an environmental pollutant: Insights on induced plant toxicity. J Bot 2012: 1-8.

PANDOLFO CM, FLOSS PA, CROCE DM AND DITTRICH RC. 2003. Resposta da erva-mate (Ilex paraguariensis St. Hil.) à adubação mineral e orgânica em um Latossolo Vermelho Aluminoférrico. Cienc Florest 13: 37-45.

POURRUT B, SHAHID M, DUMAT C, WINTERTON P AND PINELLI E. 2011. Lead uptake, toxicity, and detoxification in plants. Rev Environ Contam Toxicol 213: 113-136.

POZEBON D, DRESSLER VL, MARCELO MCA, OLIVEIRA TC AND FERRÃO MF. 2015. Toxic and nutrient elements in yerba mate (Ilex paraguariensis). Food Addit Contam Part B Surveill 8: 215-220.

REISSMANN CB, RADOMSKI MI AND QUADROS RMB. 1999. Chemical composition of Ilex paraguariensis St. Hil. Under different management conditions in seven localities of Paraná state. Braz Arch Biol Technol 42: 187-194.

SANTIN D, BENEDETTI EL, BRONDANI GE, REISSMANN CB, ORRUTÉA AG AND ROVEDA LF. 2008. Nitrogênio, fósforo e potássio no crescimento de mudas de erva-mate. Scientia Agraria 9: 59-66.

SANTIN D, BENEDETTI EL, BASTOS MC, KASEKER JF, REISSMANN CB, BRONDANI GE AND BARROS NF. 2013. Crescimento e nutrição de erva-mate influenciados pela adubação nitrogenada, fosfatada e potássica. Cien Florest 23: 365-377.

WENDLING I AND BRONDANI, G. 2015. Produção de mudas de erva-mate. In: Wendling I and Santin D (Eds), Propagação e nutrição de erva-mate. Brasília: Embrapa Informação Tecnológica, p. 11-98.

WHITE PJ. 2001. The pathways of calcium movement to the xylem. J Exp Bot 52: 891-899.

WOOD BW. 2010. Nickel deficiency symptoms are influenced by foliar $\mathrm{Zn}: \mathrm{Ni}$ and $\mathrm{Cu}: \mathrm{Ni}$ concentration ratio. Acta Hort 868: 163-169. 